\title{
ESTIMATING RECENT FOREST LOSSES IN BOSNIA AND HERZEGOVINA BY USING THE COPERNICUS AND CORINE LAND COVER DATABASES
}

\author{
PROCJENA RECENTNIH GUBITAKA ŠUME U BOSNI \\ I HERCEGOVINI KORIŠTENJEM COPERNICUS I CORINE \\ LAND COVER BAZE PODATAKA
}

Branislav DRAŠKOVIĆ ${ }^{1,2}$, Marko GUTALJ1, Stefan STJEPANOVIĆ ${ }^{1}$, Boban MILETIĆ ${ }^{1}$

\begin{abstract}
SUMIMARY
The analysis of data from the first two decades of the 21st century shows that the area under forests in Bosnia and Herzegovina is gradually decreasing. In order to gain a detailed insight into this process, the paper will analyse the forest databases of the European satellite monitoring program Copernicus. This program, among other things, monitors the condition of forests in 39 European countries by using the High Resolution Layer (HRL). The HRL Forests database consists of 3 types of (status) products, and additional change products. The status products are available for the reference years 2012, 2015, and 2018. The status layers provide information on the Dominant Leaf Type and the Tree Cover Density at pixel level for the reference year 2018 in $10 \mathrm{~m}$ resolution. The Forest Type layer largely follows the Food and Agriculture Organization (FAO) forest definition.

Also, the paper will use the data on forests from the CORINE Land Cover project for 2000, 2006, 2012 and 2018. The time-series includes a land change layer, highlighting changes in land cover and land use. The CLC Changes database will be analysed separately for three periods: 2000-2006, 2006-2012 and 2012-2018, due to more accurate data on forest losses.

The results of the research show that forests in Bosnia and Herzegovina were reduced by 2.95\%, in the period 2012-2018, where $2.55 \%$ of them were coniferous. Forests are primarily endangered by the process of conversion to transitional forest / shrub and fires.
\end{abstract}

KEY WORDS: forest, losses, B\&H, Copernicus, database, changes.

\section{INTRODUCTION}

UVOD

Bosnia and Herzegovina (B\&H) is located in the western part of the Balkan Peninsula and covers an area of 51.209 $\mathrm{km}^{2}$. It is composed of two autonomous political entities roughly equal in size: The Federation of Bosnia and Her- zegovina (FB\&H) and Republic of Srpska (RS), including a third unit as well, Brčko District (BDB\&H) which cover less than $1 \%$ of country territory. According to the last census from 2013, B\&H has about 3.53 million inhabitants (Agency for Statistics of Bosnia and Herzegovina, 2016). $\mathrm{B} \& \mathrm{H}$ is the country with the highest forest share and the

\footnotetext{
1 Prof. dr. sc. Branislav Drašković, Doc. dr. sc. Marko Gutalj, Doc. dr. sc. Stefan Stjepanović, Msc. Boban Miletić, Department of Forestry, Faculty of Agriculture, University of East Sarajevo, Bosnia and Herzegovina.

${ }^{2}$ Corresponding author: branislav.draskovic@pof.ues.rs.ba
} 
highest diversity of forest types in the Western Balkans. Forests represent one of the major natural resources of the country. Due to their natural and diverse structure, as well as extensive natural regeneration, they represent crucial resources for the further development of $\mathrm{B} \& \mathrm{H}$. The country itself is geographically excellently positioned in terms of diverse climatic influences (Mediterranean, sub Mediterranean and middle continental climate zones) and is home to over one hundred tree species. The main species found are fir, spruce, Scots and European pine, beech, various species of oak, and less significant numbers of noble broadleaves, including maples, elms, ash, together with fruit trees (cherry, apple, pear). Around 80 percent are public forests, and around 20 percent are privately owned (FAO, 2015).

Considering the area covered by forests and the complex political structure of the state, it is important to monitor the changes taking place on the ground. This is essential for improving strategic plans and use forests more efficiently as one of the most important development potentials of the state. B\&H does not have a technologically highly developed wood industry, so forest products are mainly sold as a raw materials and semi-finished products. Economic forests are defined as those forests which are actually managed for economic purposes. Non-economic forests are forests out of active management. Forest in B\&H show typical structures for countries in South-East Europe, whose characteristic is a huge amount of coppice forests.

Coppice forests amount to $12.520 \mathrm{~km}^{2}$ in total and to 8.430 $\mathrm{km}^{2}$ in productive (economic) forests, i.e. almost 40 percent of productive forests (FAO, 2015). According to same source, $51.13 \%$ belongs to high forest and $38.75 \%$ coppice forest. The rest is characterised as other wooded land and comprises shrubs, barren forest land, and other forest areas. The prevailing 9 out of 13 major European forest types illustrates the rich diversity of forests in $\mathrm{B} \& \mathrm{H}$ and the potential role forests can play in biodiversity and habitat protection, as well as a diversified portfolio of tree species and forest ecosystems in term of producing forest goods.

The most widespread type of deciduous trees is beech, which makes almost $40 \%$ compared to the distribution of all types, while oak covers around $20 \%$. Spruce and fir, which may be found at higher altitudes and that grow on steep surfaces, make an additional $20 \%$ of the forest cover in $\mathrm{B} \& \mathrm{H}$. The annual quantity of timber harvest amounted to 4.5 million $\mathrm{m}^{3} /$ year (MOFTER, 2012). European beech (Fagus sylvatica L.) is one of the most important forest tree species in $\mathrm{B} \& \mathrm{H}$, both economically and ecologically (Ballian et al, 2012).

Copernicus is the European Union's Earth Observation Programme. It offers information services based on satellite Earth observation and in situ (non-space) data. The Copernicus Land Monitoring Service (CLMS) provides geograph- ical information on land cover and its changes, land use, vegetation state, water cycle and Earth's surface energy variables to a broad range of users in Europe. Pan-European High Resolution Layers provide information on specific land cover characteristics and are complementary to land cover / land use mapping such as in the CORINE land cover (CLC) datasets. The HRLs are produced from satellite imagery through a combination of automatic processing and interactive rule based classification. Since the 2015 reference year, the production is increasingly based on time series of satellite images from a number of different sensors, including the combination of optical and radar data. The main sources are (since the 2018 reference year) the Sentinel Satellites (in particular Sentinel-2 and Sentinel-1). In addition to high resolution (HR) data, since 2015, there is very high resolution (VHR) imagery for some of the products. Since 2018, the products have increased in resolution to 10 meters, thus following the source resolution of the Sentinel-2 imagery (CLMS, 2020).

The CLC is a project launched by the European Environment Agency (EEA) more than thirty years ago with the aim of collecting, coordinating and ensuring the consistency of information on natural resources and the environment. The first CLC project for B\&H started in 1998 and was successfully completed in 2000 . The result was the creation of the B\&H CLC 2000 database, which included the identification of the types of surface cover at the level of the main classes, and also the second and third level subclass with a detailed description of the structural characteristics. Subsequently, the CLC 2006, CLC 2012, and CLC 2018 databases were created with the aim to monitor the dynamic changes in the land cover (Drašković et al, 2020).

The aims of the study are to estimate recent forest losses in B\&H by using the Copernicus and CLC database, to define the processes which endanger forest most, and to identify the CLC subclasses that are most widespread at the expense of forests.

\section{MATERIALS AND METHODS MATERIJAL I METODE}

Visual interpretation of satellite images is an important tool for monitoring spatial change trends on the Earth's surface. By collecting and analysing images from different periods, the situation on the ground can be compared and the differences and directions of spatial development can be determined. The interpretation was supported by additional data such as Orthophotomaps, local topographic maps, field data, etc.

There are variety of CLMS uses in forestry. For example, it can help to monitor the health status of forests and highlight clear cuts. The publication Ever Growing Use of Co- 
pernicus across Europe's Regions showcases, among many others, 11 user stories that describe how public administrations across Europe are using Copernicus data and information to address their challenges regarding forest issues (NEREUS, ESA and EC, 2018). Cole et al. (2018) analysing CLC changes in period 2006-2012 in the UK, found that the over $54 \%$ of changes were related to coniferous clear cutting (conversion of coniferous forest to transitional woodland /shrub).

Regarding forest, the two primary status layers Dominant Leaf Type (DLT) and Tree Cover Density (TCD) at $10 \mathrm{~m}$ spatial resolution are derived from multi-temporal Sentinel-2 satellite data from the European Space Agency (ESA) and provide information about leaf type (broadleaved/coniferous) and the proportional tree cover at pixel level (TCD in \%). The HRL Forest 2018 product portfolio already comprises a Forest Type (FTY) product. Apart from mapping the current status, it is possible to monitor change, which can be a result of manifold influences, e.g. related to climate or forestry. This is enabled by the 3 year update cycle of the HRLs which allows to not only map the loss of tree cover but also the gains (CLMS, 2020).

Some of the existing Earth Observation based products, however, require verification and tuning to meet the user requirements. For example, it was estimated that the satellite based Copernicus HRL-tree cover density layer has an overestimation error up to 7.5\% (Mirończuk and Hościło 2017; Hościło et al, 2016).

For proper management of any area, and particularly protected ones, it is essential to include as much relevant data as possible from different sectors (e.g. natural science, demography, administration, forestry, agriculture, etc.). Very often, those data have different formats, precision, resolution, origin, etc. A geographic information system (GIS) enables successful integration of such diverse data into a harmonized database containing all data in compatible format (Marić-Limari et al, 2017).

A Digital Elevation Model (EU DEMv1.1.) with a resolution of $25 \mathrm{~m}$ and the FTY 2018 layer with a resolution of 10 $\mathrm{m}$ have been used to view the spatial distribution of forest types by altitude zones. By using the GIS tool Raster Cal- culator, the areas under broad-leaved and coniferous forests have been calculated by altitude zones. Considering the altitude range from 0 to $2367 \mathrm{~m}$, four altitude zones of 0-500 $\mathrm{m}$ (39.47\% of the B\&H territory), $500-100 \mathrm{~m}$ (35.53\%), $1000-1500 \mathrm{~m} \mathrm{(21.9 \% )}$ and over $1500 \mathrm{~m}(3.1 \%)$ have been taken into account. According to Stjepanović (2019), among the main species of forest in the zone with an altitude of less than $500 \mathrm{~m}$, the most common ones are sessile oak forests, covering about $95 \%$ of the area, in the hilly zone (500-1000 m) there are beech forests with $47 \%$ of the area, and in the mountain zone (1000-1500 m) there are beech and spruce forests with $71 \%$ of the area.

CLC Changes data for the B\&H territory have been extracted by using the GIS software and changes in the form of polygons for all three periods have been visualized. The data have been exported to Microsoft Excel and classified by type of change. The individual sum of areas of all land cover types and changes by periods have been calculated by using the Sort \& Filter and Subtotal Sum tools. Through the processing of this data, we get a spatial and temporal insight into all the processes that take place in the field.

\section{RESULTS AND DISSCUSION REZULTATI I DISKUSIJA}

The total area under forests in B\&H in 2018 was 30498.57 $\mathrm{km}^{2}$ or $59.55 \%$ of the territory, which is a decrease by $2.94 \%$. in comparison with 2012. Broad-leaved forests decreased by $0.39 \%$ and coniferous forests by $2.55 \%$. Among the forest types in 2018, broad-leaved forests account for $80.98 \%$, while coniferous forests account for $19.02 \%$. In comparison with 2012, when broad-leaved forest covered $77.78 \%$ and coniferous forest $22.22 \%$ (Table 1), this is a significant change.

Distinguishing forest area losses (i.e. conversion to non-forest land uses or deforestation) from tree cover losses, which may be temporary (i.e. natural disturbances, sustainable forestry) or which may eventually lead to forest area loss (i.e. unsustainable logging, altered successional pathways), is critically important for two reasons. Firstly, the impacts of permanent loss in forest area on biodiversity, ecosystem functioning, and resource use opportunities are fundamentally

Table 1: Dominant leaf types in B\&H in the period 2012-2018 (DLT 2018 resolution 10 m, DLT 2015 and DLT 2012 resolution 20 m.) (Source: CLMS, DLT database)

Tablica 1: Šume prema dominantnom tipu lista u BiH u periodu 2012-2018. (DLT rezolucija 10 m, DLT 2015 i DLT 2012 rezolucija 20 m) (Izvor: CLMS, DLT baza podataka)

\begin{tabular}{lcccccccccc} 
Forest /Šuma & \multicolumn{3}{c}{ DLT 2012} & \multicolumn{3}{c}{ DLT 2015} & \multicolumn{3}{c}{ DLT 2018} \\
Broad-leaved/Listopadna & 24894.34 & 77.78 & 48.61 & 25221.80 & 78.85 & 49.25 & 24696.44 & 80.98 & 48.22 \\
Coniferous/Četinarska & 7110.55 & 22.22 & 13.88 & 6764.67 & 21.15 & 13.21 & 5802.13 & 19.02 & 11.33 \\
Total/Ukupno & 32004.89 & 100.00 & 62.49 & 31986.47 & 100.00 & 62.46 & 30498.57 & 100.00 & 59.55
\end{tabular}


Table 2: Dominant leaf types in 2018. by B\&H entities (Source: CLMS, DLT 2018 database)

Tablica 2: Dominantni tipovi lista u 2018 po BiH entitetima (Izvor: CLMS, DLT 2018 baza podataka)

\begin{tabular}{|c|c|c|c|c|c|c|c|c|c|}
\hline \multirow[t]{2}{*}{ DLT 2018} & \multicolumn{3}{|c|}{$\begin{array}{c}\text { Federation B\&H } \\
\text { Federacija BiH }\end{array}$} & \multicolumn{3}{|c|}{$\begin{array}{l}\text { Republic of Srpska } \\
\text { Republika Srpska }\end{array}$} & \multicolumn{3}{|c|}{$\begin{array}{l}\text { Brčko District } \\
\text { Brčko Distrikt }\end{array}$} \\
\hline & $\mathrm{P}\left(\mathrm{km}^{2}\right)$ & $\%$ & $\%$ of FB\&H & $\mathrm{P}\left(\mathrm{km}^{2}\right)$ & $\%$ & $\%$ of RS & $\mathrm{P}\left(\mathrm{km}^{2}\right)$ & $\%$ & $\%$ of $\mathrm{BD}$ \\
\hline Broad-leaved/Listopadna & 13318.79 & 78.35 & 51.07 & 12096.07 & 81.64 & 49.08 & 192.22 & 97.61 & 38.94 \\
\hline Coniferous/Četinarska & 3680.52 & 21.65 & 14.11 & 2720.18 & 18.36 & 11.04 & 4.70 & 2.39 & 0.95 \\
\hline Total/Ukupno & 16999.31 & 100.00 & 65.19 & 14816.25 & 100.00 & 60.12 & 196.92 & 100.00 & 39.89 \\
\hline
\end{tabular}

different than the impacts of a temporary loss of forest cover. Secondly, different policy and management responses are needed to achieve sustainability in the face of forest area versus forest cover losses (Wulder et al, 2020).

According to the same database, $65.19 \%$ of the territory the Federation of $\mathrm{B} \& \mathrm{H}$ is covered by forests, where $51.07 \%$ are broad-leaved and $14.11 \%$ are coniferous, while $60.12 \%$ of the Republic of Srpska is covered by forests, where $49.08 \%$ are broadleaved and $11.04 \%$ are coniferous. In the Brčko District, the forest covers 39.89\%, of which broadleaved forests cover $38.94 \%$, and the coniferous forest only 0.95\% (the Brčko District occupies a small, mostly urban territory, predominantly between $100-200 \mathrm{~m}$ above sea level) (Table 2).

According to the DLT Change database in the period 20152018, broad-leaved forest losses amounted to $55.22 \mathrm{~km}^{2}$, which is $0.22 \%$ of the total area covered under this type of forest. Coniferous forest losses in the same period amounted to $25.25 \mathrm{~km}^{2}$ or $0.37 \%$ in comparison with the initial year. Potential change among dominant leaf types is 2.38 $\mathrm{km}^{2}$ or $0.01 \%$ of total forest cover (Table 3 ).

FAO defines a forest as a land with tree crown cover (or equivalent stocking level) of more than 10 percent and area of more than 0.5 hectares (ha). The trees should be able to reach a minimum height of 5 meters $(\mathrm{m})$ at maturity in situ. May consist either of closed forest formations where trees of various storeys and undergrowth cover a high proportion of the ground; or open forest formations with a continuous vegetation cover in which tree crown cover exceeds 10 percent. Young natural stands and all plantations established for forestry purposes which have yet to reach a crown density of 10 percent or tree height of $5 \mathrm{~m}$ are included under forest, as are areas normally forming part of the forest
Table 3: Dominant leaf type changes in B\&H in period 2015-2018 (20 $\mathrm{m}$ resolution) (Source: CLMS, DLT Change database)

Tablica 3: Promjene prema dominantnom tipu lista u BiH u periodu 20152018. (20 m rezolucija) (Izvor: CLMS, DLT Change baza podataka)

\begin{tabular}{lccc} 
Class Name / Naziv klase & $\mathrm{P}\left(\mathrm{km}^{2}\right)$ & $\%$ of $\mathrm{B} \& \mathrm{H}$ & $\begin{array}{c}\text { \% of total forest } \\
\% \text { od ukupne šume }\end{array}$ \\
$\begin{array}{l}\text { Loss of broadleaved forest / } \\
\begin{array}{l}\text { Gubitak listopadne šume } \\
\text { Loss of coniferous cover / }\end{array}\end{array}$ & 55.22 & 0.11 & 0.22 \\
$\begin{array}{l}\text { Gubitak četinarske šume } \\
\begin{array}{l}\text { Potential change among } \\
\text { dominant leaf types / }\end{array}\end{array}$ & 25.25 & 0.05 & 0.37 \\
$\begin{array}{l}\text { Potencijalne promjene među } \\
\text { dominantnim tipovima lista }\end{array}$ & 2.38 & 0.00 & 0.01 \\
\hline
\end{tabular}

area which are temporarily unstocked as a result of human intervention or natural causes but which are expected to revert to forest (FAO, 1998).

FTY layer is derived through a spatial intersection of the two primary status layers TCD and DLT and excludes areas under agricultural use and in urban context. The FTY database shows a more intense trend of decreasing the forest area compared to the DLT database. Namely, in the period 2012-2018, a decrease in the area under forests was recorded in the amount of $4.78 \%$, of which conifers accounted for $2.66 \%$ and broad-leaved trees for $2.13 \%$. The ratio within forests is similar: broad-leaved forests increase from $77.7 \%$ in 2012 to $80.47 \%$ in 2018 , while conifers decrease from $13.87 \%$ in 2012 to $11.21 \%$ in 2018 (Table 4).

By overlapping the raster layers EU DEMv1.1 and FTY 2018, the spatial distribution of forest types by altitude zones has been obtained (Figures 1 and 2). About $75 \%$ of the territory of B\&H is below $1000 \mathrm{~m}$ and $25 \%$ above. As it could be expected, broad-leaved forests dominate at lower

Table 4: Forest types in B\&H in period 2012-2018 (Source: CLMS, FTY database)

Tablica 4: Tipovi šuma u BiH u period 2012-2018 (Izvor: CLMS, FTY baza podataka)

\begin{tabular}{lcccccccccc}
\multicolumn{1}{c}{ Forest Type/ } & \multicolumn{3}{c}{ FTY 2012} & & \multicolumn{3}{c}{ FTY 2015} & \multicolumn{3}{c}{ FTY 2018} \\
\multicolumn{1}{c}{ Tip šume } & $\mathrm{P}\left(\mathrm{km}^{2}\right)$ & $\%$ & $\%$ of B\&H & $\mathrm{P}\left(\mathrm{km}^{2}\right)$ & $\%$ & $\%$ of B\&H & $\mathrm{P}\left(\mathrm{km}^{2}\right)$ & $\%$ & $\%$ of B\&H \\
Broad-leaved/Listopadna & 24748.40 & 77.70 & 48.32 & 24748.4 & 78.53 & 48.32 & 23658.09 & 80.47 & 46.19 \\
Coniferous/Četinarska & 7104.34 & 22.30 & 13.87 & 6765.28 & 21.47 & 13.21 & 5743.44 & 19.53 & 11.21 \\
Total/Ukupno & 31852.74 & 100.00 & 62.19 & 31513.68 & 100.00 & 61.53 & 29401.53 & 100.00 & 57.41
\end{tabular}


Table 5: Forest types in B\&H by elevation zones (Source: CLMS, FTY 2018 database) Tablica 5: Tipovi šuma u BiH po visinskim zonama (Izvor: CLMS, FTY 2018 baza podataka)

\begin{tabular}{lcccccc} 
Altitude/Visina & $0-500 \mathrm{~m}$ & $500-1000 \mathrm{~m}$ & $1000-1500 \mathrm{~m}$ & $>1500 \mathrm{~m}$ & Total/Ukupno \\
\hline Broad-leaved \% / Listopadna \% & 38.65 & 41.91 & 17.77 & 1.66 & 100.00 \\
Coniferous \% / Četinarska \% & 8.16 & 30.22 & 57.82 & 3.80 & 100.00
\end{tabular}

altitudes and coniferous forests at higher altitudes. Broadleaved forests occupy $80.56 \%$ of the area up to $1000 \mathrm{~m}$, while coniferous forests in the area over $1000 \mathrm{~m}$ cover $61.62 \%$. In mountainous areas, with an altitude of over $1500 \mathrm{~m}$, forests are represented by $5.46 \%$, of which $3.8 \%$ are coniferous and $1.66 \%$ are broad-leaved (Table 5).

The Copernicus HRL Forest defines Tree Cover Density as the ,vertical projection of tree crowns to a horizontal earth's surface" and provides information on the proportional crown coverage per pixel (Figure 3). Tree Cover Density is assessed on VHR sources by visual interpretation following a point grid approach and subsequently transferred to the HR data by a linear function. In particular, information on

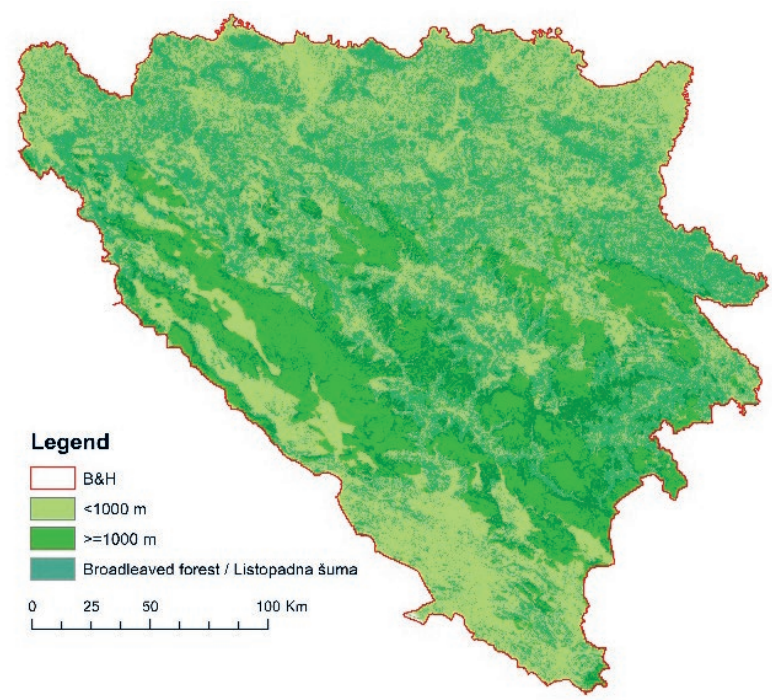

crown cover, which is provided with the continuous-scale (0-100\%) TCD product for the whole of Europe, can be generally used by different countries, even if different national forest definition regarding the crown/canopy cover exist (e.g. Austria with 3\%, Spain with 5\%) (CLMS, 2018).

Table 6 shows the level of tree cover density in a range from 0 to $100 \%$. The tree cover density over $10 \%$ refers to $99.9 \%$ of the forest. The density of $51-100 \%$ refers to $92.6 \%$ of the forest. For the TCD 2018 database, consistent multi-temporal coverage refers to the period 01 March 2018 - 31 October 2018. Although unsustainable wood removal, including illegal harvesting, is sometimes regarded as a cause of deforestation, it is more often associated with forest degra-

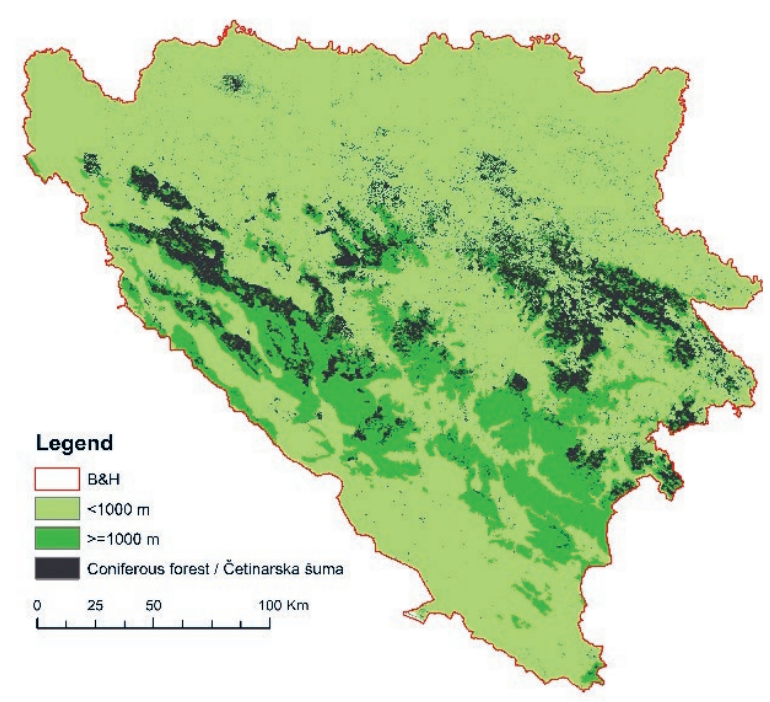

Figure 1 and 2: Spatial distribution of broad-leaved and coniferous forest in B\&H (Source: CLMS, 2020, FTY 2018 database) Slike 1 i 2: Prostorna distribucija listopadne i četinarske šume u BiH (Izvor: CLMS, 2020, FTY 2018 baza podataka)

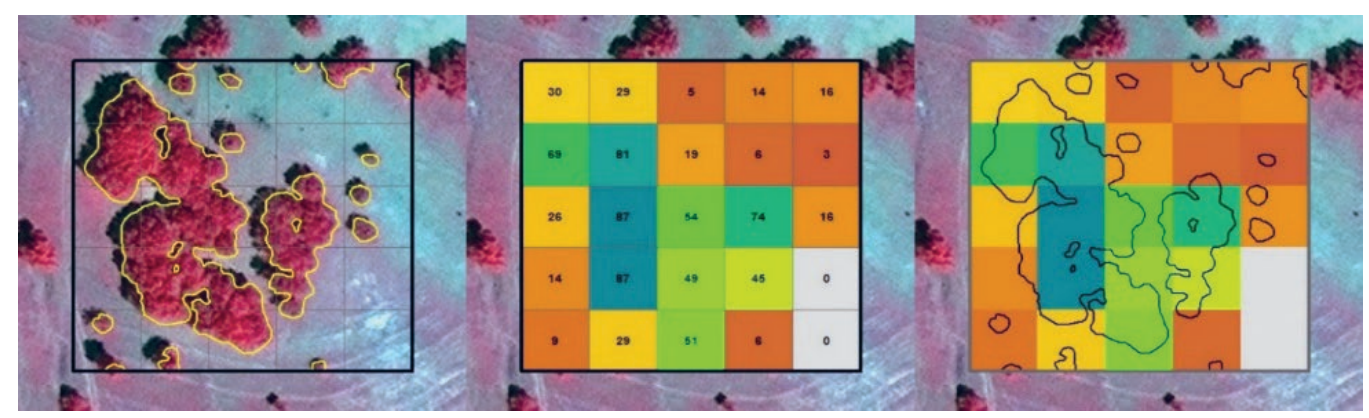

Figure 3: Ideal-typical illustration of the Tree Cover Density product, delineated from a VHR satellite scene, $20 \mathrm{~m}$ raster grid (Source: CLMS, 2018) Slika 3: Idealno-tipična ilustracija gustine šumskog pokrivača, ucrtanog sa VHR satelitske scene, 20 m rasterska mreža (Izvor: CLMS, 2018) 
Table 6: Tree cover density in BCH in period 2012-2018 (TCD 2018 layer resolution 10 m, TCD 2015 and TCD 2012 layers resolution 20 m) (Source: CLMS, TCD database)

Tablica 6: Gustina šumskog pokrivača u BiH u periodu 2012-2018 (TCD 2018 sloj rezolucija 10 m, TCD 2015 i TCD 2012 slojevi rezolucija 20 m) (Izvor: CLMS, TCD baza podataka)

$\begin{array}{lcccccccccccc}\% & 1-10 & 11-20 & 21-30 & 31-40 & 41-50 & 51-60 & 61-70 & 71-80 & 81-90 & 91-100 & \text { Total/Ukupno } \\ \text { TCD 2012 } & 0.5 & 1 & 1.4 & 1.8 & 3.2 & 5.7 & 9.6 & 15.6 & 36.3 & 24.8 & 100 \\ \text { TCD 2015 } & 0 & 0 & 0.1 & 0.3 & 1.3 & 4.1 & 9.3 & 21.1 & 49.5 & 14.3 & 100 \\ \text { TCD 2018 } & 0.1 & 0.3 & 0.7 & 1.7 & 4.8 & 12.2 & 22.6 & 28.6 & 21.1 & 8.1 & 100\end{array}$

Table 7: Forest losses by main types of land cover and periods $\left(\mathrm{km}^{2}\right)$ (Source: CLMS, CLC CHA database)

Tablica 7: Šumski gubitci prema glavnim tipovima površinske pokrovnosti i po periodima (km²) (lzvor: CLMS, CLC CHA baza podataka)

\begin{tabular}{|c|c|c|c|c|}
\hline Changes/Promjene & 2000-2006 & 2006-2012 & 2012-2018 & Total \\
\hline Forest to Artificial surfaces / Šume $u$ vještačke površine (3.1.x-1.x.x $)^{3}$ & 5.69 & 3.83 & 4.38 & 13.90 \\
\hline Forest to Agricultural land / Šume u poljoprivredno zemljište (3.1.x-2.x.x) & 0.82 & 1.29 & 1.63 & 3.74 \\
\hline $\begin{array}{l}\text { Forest to Shrub and/or herbaceous vegetation associations / } \\
\text { Šume } u \text { grmovitu i/ili travnatu vegetaciju (3.1.x-3.2.x) }\end{array}$ & 179.63 & 18.68 & 46.09 & 244.40 \\
\hline $\begin{array}{l}\text { Forest to Open spaces with little or no vegetation / } \\
\text { Šume } u \text { otvorene prostore sa malo ili bez vegetacije (3.1.x-3.3.x) }\end{array}$ & 5.98 & 19.56 & 14.32 & 39.86 \\
\hline Forest to Water bodies / Šume $u$ vodna tijela (3.1.x-5.x.x) & 0.55 & 0.41 & 0.13 & 1.09 \\
\hline Total losses / Ukupni gubitci & 192.67 & 43.77 & 66.55 & 302.99 \\
\hline Internal forest conversion / Interna šumska konverzija (3.1.x-3.1.x) & 6.05 & 2.78 & 0.31 & 9.14 \\
\hline Other to forest / Drugi tipovi u šume (x.x.x-3.1.x) & 95.12 & 84.24 & 13.94 & 193.30 \\
\hline Net losses/ Neto gubitci & -97.55 & 40.47 & -52.61 & -109.69 \\
\hline
\end{tabular}

dation because wood removal does not necessarily lead to changes in land use (FAO, 2016). It can refer to reducing of tree cover density, considering the fact that the data in Table 6 shows the decrease of $81-90 \%$ and of $91-100 \%$ in 2018.

\section{Forest losses by LC/LU subclasses - Gubitci šuma po LC/LU podklasama}

In 2019, the European Environment Agency (EEA) published an updated illustrated guide to the nomenclature of land cover types with a structural classification at three hierarchical levels and a differentiated level of detail (EEA, 2019). According to the CLC 2018 database, forests cover $46.34 \%$ of the territory of $\mathrm{B} \& \mathrm{H}$, broad-leaved $32.62 \%$, coniferous $5.28 \%$ and mixed $8.45 \%$. In comparison with the CLC 2000, the increase in forest areas was about 2\% (Drašković, 2020). However, the CLC Changes database for the period 2000-2018 reduced the forest area by $109.69 \mathrm{~km}^{2}$, i.e. they occupy $0.34 \%$ less territory compared to the initial year (Table 7). This difference arose because CLC and CLC Changes databases use different spatial units. CLC uses a Minimum Mapping Unit (MMU) of 25 ha for areal phenomena and a minimum width of $100 \mathrm{~m}$ for linear phe- nomena, while changes (CHA) in land cover uses an MMU of 5 ha.

Similar to the CLC Changes database, DLT 2018 and FTY 2018 databases have slightly different data compared to CLC 2018. According to the CLC 2018, forest covers 11.07\% less of the territory in comparison with the FTY 2018. There are two main reasons for that: the lower resolution of the CLC database and the different classification nomenclature of forest types. The FTY 2018 database mainly includes transitional woodland / shrub, while this subclass (3.2.4) in the CLC 2018 database is separated from forests (3.1.x). ${ }^{4}$ If we added the transitional woodland / shrub (or at least part of the area) to the forests, the data for both bases would roughly match.

From Figure 4, the structure of losses of all three forest types (broadleaved, coniferous and mixed) can be seen. Broadleaved forest (3.1.1) is most susceptible to losses is, especially in the transitional woodland / shrub (3.2.4) in the first period. The total losses of broad-leaved forest to transitional woodland / shrub in the period 2000-2018 were 202.73 $\mathrm{km}^{2}$. However, it is a two-way process. In the same period,

\footnotetext{
${ }^{3} \mathrm{x}$ can be any number from 1 to 4 and also 5 for the first column.

${ }^{4}$ Transitional woodland/shrub includes young broad-leaved and/or coniferous trees; damaged or dead trees and shrubs, fully grown trees, covering $<30 \%$ of area, etc. When vegetation formation of the above-mentioned composition of broad-leaved deciduous and coniferous trees and shrubs represent some transitional stage of forest development, then it should be classified as transitional woodland/shrub (3.2.4) (EEA, 2019).
} 


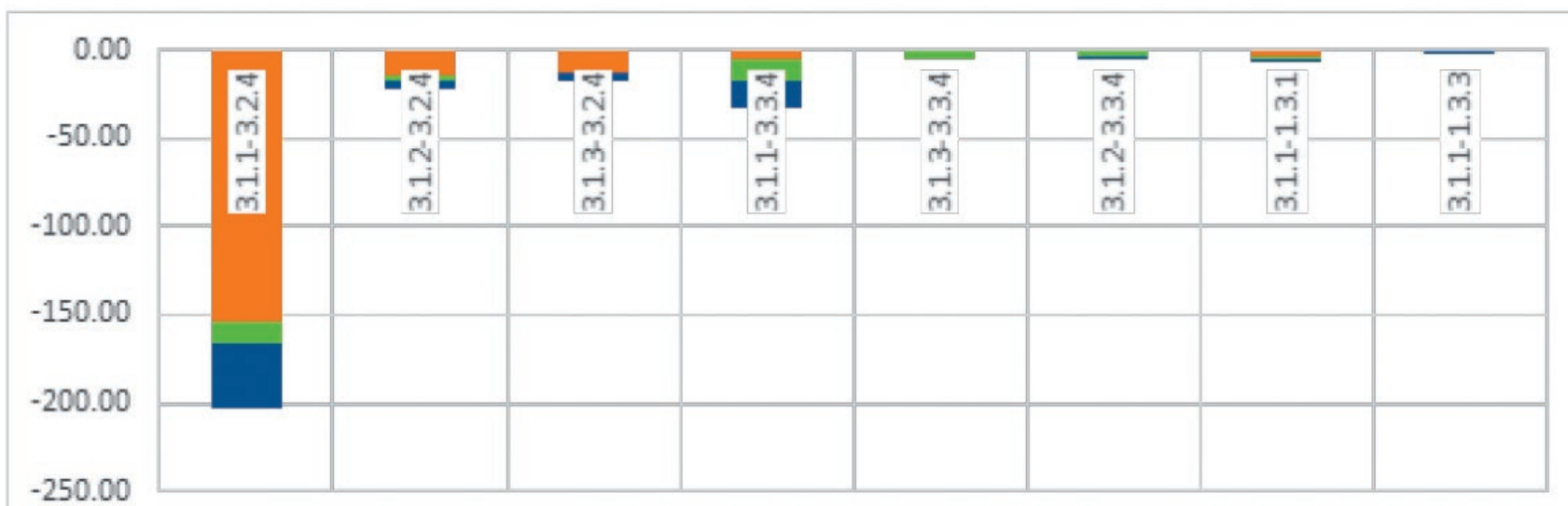

ص CODE 3.1 Losses/Gubitci 2000-2006 nCODE 3.1 Losses/Gubitci 2006-2012 m CODE 3.1 Losses/Gubitci 2012-2018

Figure 4: Structure of forest losses by periods $\left(\mathrm{km}^{2}\right)$

Slika 4: Struktura gubitaka šuma po periodima $\left(\mathrm{km}^{2}\right)$

Table 8: Most significant land cover types on third level of classification caused forest losses (Source: CLMS, CLC CHA database) Tablica 8: Najznačajnije promjene tipova površinske pokrovnosti na trećem nivou klasifikacije koje uzrokuju šumske gubitke (Izvor: CLMS, CLC CHA baza podataka)

$\begin{array}{lcccccc}\text { Changes/Promjene } & \mathrm{P}\left(\mathrm{km}^{2}\right) & \text { \% of losses / \% od gubitaka } & \mathrm{P}\left(\mathrm{km}^{2}\right) & \text { \% of losses / \% od gubitaka } & \mathrm{P}\left(\mathrm{km}^{2}\right) & \text { \% of losses / \% od gubitaka } \\ \text { 3.1-3.2.4 } & 179.36 & 93.09 & 18.69 & 42.60 & 46.09 & 69.25 \\ \text { 3.1-3.3.4 } & 5.98 & 3.10 & 19.65 & 42.12 & 14.18 & 21.21 \\ \text { Total/Ukupno } & 185.34 & 96.19 & 38.34 & 84.73 & 60.27 & 90.45\end{array}$

the spread of broad-leaved forest over the transitional woodland / shrub was $152.33 \mathrm{~km}^{2}$. Therefore, the losses are covered with $75 \%$, i.e. the net losses amount to $50.4 \mathrm{~km}^{2}$. It is noteworthy that clear cutting of forest (3.1-3.2.4) far exceeds replanting (3.2.4-3.1), however the slow regrowth of forestry is more difficult to map consistently. The next biggest cause of forest losses are fires, to which broad-leaved forests are also most exposed. The conversion of this type into the burnt area (3.1.1-3.3.4) increases from period to period: in the first period broad-leaved forest was affected by fires in an area of $5.68 \mathrm{~km}^{2}$, in the second $12.21 \mathrm{~km}^{2}$ and in the third $14.1 \mathrm{~km}^{2}$.

The causes of forest losses can be different: human made (illegal logging, over-exploitation of wood resources, etc.), plant diseases, fires etc. All the recorded fires have occurred in the south of the country, in the region of Herzegovina, known for its Mediterranean climate with high temperatures and low rainfall in the summer season. The most affected zones have occurred within Trebinje city local area and Herzegovina-Neretva canton (Drašković et al, 2020a).
Internal conversion from one type of forest to another has not been very common. In the first period, $6.05 \mathrm{~km}^{2}$ have been noted (the conversion of the broad-leaved forest to mixed in the amount of $3.27 \mathrm{~km}^{2}$ and of the mixed to the coniferous with $2.78 \mathrm{~km}^{2}$ ), in the second period $2.78 \mathrm{~km}^{2}$ (broad-leaved to coniferous $0.17 \mathrm{~km}^{2}$ and mixed to coniferous $2.61 \mathrm{~km}^{2}$ ), and in the third period only $0.31 \mathrm{~km}^{2}$ (coniferous to mixed). This is not an actual loss, since one type of forest has been replaced by another.

Table 8 shows the processes that cause the forest losses have been related to the conversion of forests into transitional woodland / shrub. ${ }^{5}$ In the first period, the conversion of forests into transitional woodland / shrub has been $93.09 \%$, in the second $42.6 \%$ and in the third $69.25 \%$ of all the changes.

The second biggest cause of forest losses is related to fires. During the first period, the conversion of forests into burnt areas has included $3.1 \%$, in the second $42.12 \%$ and in the third $21.21 \%$ of total losses. This class (3.3.4) is applicable for recent burns of forest (classes 3.1.x) still visible in the satellite images.

\footnotetext{
${ }^{5}$ Transitional process can be for instance natural succession on abandoned agricultural land, regeneration of forest after damages of various origin (e.g. storm, avalanche), stages of forest degeneration caused by natural or anthropogenic stress factors (e.g. drought, pollution), reforestation after clearcutting, afforestation on formerly non-forested natural or semi-natural areas etc. (EEA, 2019).
} 


\section{CONCLUSIONS ZAKLJUČCI}

The DLT 2018 high-resolution database $(10 \mathrm{~m})$ shows that forests cover $59.55 \%$ of the territory of $\mathrm{B} \& \mathrm{H}$, of which $80.98 \%$ are broad-leaved and $19.02 \%$ coniferous. According to the same database, the coverage of forests in $\mathrm{B} \& \mathrm{H}$ has reduced by $2.94 \%$ in the period 2012-2018. This primarily refers to conifers that participate in the overall decrease of $2.55 \%$. The area of coniferous forests in B\&H decreased from $22.22 \%$ in 2012 to $19.02 \%$ in 2018 . The Forest type (FTY) databases show a similar trend. Broad-leaved forests are mainly positioned in lower areas, below 1000 $\mathrm{m}$, with $80.56 \%$, while conifers are in higher areas, above $1000 \mathrm{~m}$, with $61.62 \%$. The tree cover density database shows relatively high spatial distribution of forest density. The tree cover density over $50 \%$ accounts for $91.6 \%$ of the forest area.

According to the CLC Changes database in the period 20002018 forest losses have been $109.69 \mathrm{~km}^{2}$ or $0.34 \%$ of territory, in comparison with the initial year. The largest forest losses are related to conversion to transitional woodland / shrub and burnt areas, which account for $93.68 \%$ of all losses. The process of conversion to transitional woodland / shrub was most intense in the first period (2000-2006). In comparison with the first period, the fires were somewhat more intense in the second (2006-2012) and third (20122018) one. Losses of broad-leaved forest into transitional woodland / shrub were equally distributed throughout the entire territory of $\mathrm{B} \& \mathrm{H}$, while fires endangered the southern part of the country most, i.e. the region of Herzegovina. Among the other forest losses, artificial areas are the cause of $4.59 \%$ of forest losses (various anthropogenic processes), and agricultural land has a share of $1.23 \%$.

The reasons for different results obtained by using Forest 2018 and CLC 2018 databases are the different spatial resolution and classification nomenclature. Namely, the CLC has lower resolution and does not include subclass transitional woodland /shrub (3.2.4) in a forest subclass (3.1).

\section{REFERENCES LITERATURA}

- Agency for statistic of Bosnia and Herzegovina, 2016: Census of Population, Households and Dwellings in Bosnia and Herzegovina, 2013. Sarajevo. http://www.statistika.ba/ (accessed 15 November 2020).

- Ballian, D., Bogunić, F., Mujezinović, O., Kajba, D., 2012: Genetska diferencijacija obične bukve (Fagus sylvatica L.) u Bosni i Hercegovini. Šumarski list 11-12, (2012): 587-595., Zagreb.

- Cole B., Smith G., Balzter H. 2018: Acceleration and fragmentation of CORINE land cover changes in the United Kingdom from 2006-2012 detected by Copernicus IMAGE2012 satellite data, Int J Appl Earth Obs Geoinformation 73, 107-122.
- Copernicus Land Monitoring Services (CLMS): https://land. copernicus.eu/pan-european, CLC and CHA database (accessed 03 January 2020).

- Copernicus Land Monitoring Service (CLMS): European Digital Elevation Model (EU-DEM), version 1.1. database. https:// land.copernicus.eu/imagery-in-situ/eu-dem/eu-dem-v1.1/view (accessed 05 January 2021)

- Copernicus Land Monitoring Services, (CLMS): Forest, database. https://land.copernicus.eu/pan-european/high-resolution-layers/forests (accessed 05 January 2021)

- Copernicus Land Monitoring Services (CLMS), 2020: Tree cover/forest and change 2015-2018, User Manual.

- Copernicus Land Monitoring Service (CLMS), 2018: High Resolution Layer Forest, Product Specifications Document. https:// land.copernicus.eu/user-corner/technical-library/hrl-forest

- Drašković B., 2020: Trends of spatial development in Bosnia and Herzegovina, Journal Geographical Review, Vol 42, pp 57 67., Sarajevo.

- Drašković B, Ponosov A, Zhernakova N, Gutalj M, Miletić B., 2020: Land cover types and changes in land use in Republic of Srpska (Bosnia and Herzegovina) over the period 2000-2018. Journal of the Geographical Institute "Jovan Cvijić" SASA, 70 (1), pp 81-88., Belgrade.

- Drašković B, Miletić B, Gutalj M, Stjepanović S., 2020a: Climate changes and fires in Bosnia and Herzegovina, XI International Scientific Agriculture Symposium „AGROSYM 2020“, pp 694702., East Sarajevo.

- European Environment Agency (EEA), 2019: CORINE Land Cover Nomenclature Guidelines, https://land.copernicus.eu/ user-corner/technical-library/corine-land-cover-nomenclature-guidelines/html

- FAO, 2016: State of World's forests, Forest and Agriculture, Land-use: Challenges and opportunities, http://www.fao.org/3/ a-i5588e.pdf (accessed 9 January 2021).

- FAO, 2015: Regional Office for Europe and Central Asia, Forest Sector in Bosnia and Herzegovina. http://www.fao. org/3/a-au015e.pdf (accessed 10 January 2021).

- FAO, 1998: FRA 2000 on definitions of forest and forest change (fao.org)

- www.fao.org/docrep/006/ad665e/ad665e06.htm (accessed 10 January 2021).

- Hościło A., Mirończuk A., Lewandowska A., 2016: Określenie rzeczywistej powierzchni lasów w Polsce na podstawnie dostępnych danych przestrzennych, Sylwan, Vol. 160, No 8, pp 627-634.

- NEREUS, European Space Agency and European Commission (NEREUS, ESA and EC), 2018: "The Ever Growing use of Copernicus across Europe's Regions: a selection of 99 user stories by local and regional authorities", pp 277.

- Marić-Limari S., Tišma S., Pisarović A., Jelaska S., 2017: Spatial analysis of landcover and relief diversity of the Medvednica natural park - possible implications for optimising visitor pressure, Šumarski list 11-12, (2017): 547-555., Zagreb.

- Mirończuk A., Hościło A., 2017: Mapping tree cover with Sentinel-2 data using the Support Vector Machine (SVM), Geoinformation Issues Vol. 9, No 1 (9), 27-38.

- Ministry of Foreign Trade and Economic Relations (MOFTER), 2012: State of the Environment Report of Bosnia and Herzegovina. 
- https://www.unenvironment.org/resources/report/state-environment-report-bosnia-and-herzegovina (accessed 15 January 2021).

- Stjepanović S., 2019: Uticaj klime na rast i vitalnost stabala u zavisnosti od horizontalnog i vertikalnog rasprostranjenja bukovih šuma, Disertacija, Poljoprivredni fakultet Novi Sad.
- Wulder M. A., Hermosilla T., Stinson G., Gougeon F. A., White J. C., Hill D. A. and Smiley B. P., 2020: Satellite-based time series land cover and change information to map forest area consistent with national and international reporting requirements, Forestry: An International Journal of Forest Research, Vol. 93, Issue 3, 331-343.

\section{SAŽETAK}

Analiza podataka iz prve dvije dekade 21. stoljeća pokazuje da se teritorija pod šumom u Bosni i Hercegovini postepeno smanjuje. Da bi dobili detaljan uvid u taj proces u radu će biti analizirana baza podataka o šumama Europskog satelitskog monitoring programa Copernicus. Ovaj program, između ostalog, prati stanje šuma u 39 europskih zemalja koristeći bazu podataka slojeva visoke rezolucije High Resolution Layer (HRL). HRL Forest baza podataka sadrži tri tipa (statusnih) produkata i dodatni produkt o promjenama. Statusni produkti su dostupni za 2012, 2015. i 2018. godinu. Statusni slojevi daju informacije o dominantnom tipu lista i gustini šumskog pokrivača na pikselskom nivou za referentnu godinu 2018. prostorne rezolucije $10 \mathrm{~m}$. Forest Type sloj u najvećem dijelu prati FAO definiciju šume.

Osim toga, u radu će biti korišteni podaci CORINE Land Cover (CLC) projekta za 2000, 2006, 2012. i 2018. godinu. Vremenska serija uključuje i sloj o promjenama, koji prikazuje promjene u tipovima površinske pokrovnosti i načinu korištenja zemljišta. Baza podataka o promjenama (CLC Changes) za sva tri perioda bit će analizirana zasebno: 2000-2006, 2006-2012. i 2012-2018, radi veće preciznosti podataka o gubitcima šumskog tla. Rezultati istraživanja pokazuju da su šume u $\mathrm{BiH}$ u periodu 2012 2018. smanjile površinu za 2,95\%, od čega su 2,55\% četinari. Šume su najugroženije procesima konverzije u tranzicijsku šumu/šikaru i požarima.

KLJUČNE RIJEČI: šuma, gubitci, BiH, Copernicus, baza podataka, promjene. 